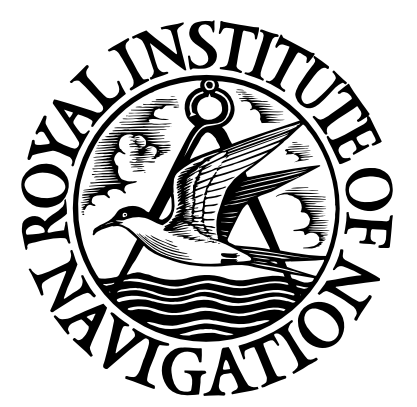

\title{
THE JOURNAL OF NAVIGATION
}

\begin{tabular}{lll}
\hline VOL. 52 & MAY 1999 & NO. 2
\end{tabular}

\section{PRESIDENTIAL ADDRESS}

In his Presidential Address at the 52nd Annual General Meeting of the Institute, held in London on 21 October 1998, Air Commodore Pinky Grocott gave an analysis of the causal factors that resulted in the loss of 913 large sailing ships during the period of the Revolutionary and Napoleonic eras (1793-1815). Navigation and weather factors predominated, often aggravated by poor and untimely decision-making. Many of the lessons learnt are equally relevant today.

\section{Shipwrecks in the Revolutionary and Napoleonic Eras, 1793-1815. Causal Factors and Comments}

\section{Air Commodore D. F. H. Grocott}

1. INTRODUCTION. If any one period could be described as the age of sail it would be the period of the Revolutionary and Napoleonic Eras, a period lasting from 1793 to 1815. During this period, war raged between England and France, and our North American colonies were proving more than a little troublesome. Thus, it is not surprising that throughout this period the Royal Navy operated relatively large fleets of sailing ships and escorted convoys of merchantmen to the West Indies and to the Mediterranean

Life at sea was hard, and there was a severe shortage of qualified seamen to man the many warships. The few men who were qualified showed little enthusiasm to serve on one of the naval ships of HM George III. They preferred instead to serve with shipping companies, such as the East Indies Company, a company that allowed sailors to take members of their families with them from time to time. Because of the severe shortage of seamen, the Government saw fit to rely on the Impress Service, whereby qualified seamen and others could be seized on the street, in houses 
frequented by seamen, or on the high seas, and pressed to serve for a term in HM Navy. Not the makings for a happy ship or to inculcate the spirit required to furl the main topgallant sails in a Force 9 gale. The record shows that between 1790 and 1815 some 10,000 seamen were even taken off American ships, much to the annoyance of the US Congress.

Navigation using the sextant and chronometer was being practised on direct A-to-B voyages, the precision marine sextant having been invented in 1730 and the chronometer in 1763. Charts and sailing directions were available but, when compared with modern-day charts, they were at best incomplete and at worst inaccurate and misleading. Sailing in foreign waters posed a particular difficulty, there being a need for exceptionally good lookouts to spot uncharted shoals or rocks that might be directly in a vessel's path.

The sailing ships were powered by canvas alone and lacked manoeuvrability. Manoeuvrability is, of course, a relative term. To put it into perspective, while a modern yacht may sail to within 30 degrees to the wind, the sailing ships of the revolutionary era were regarded as good if they could sail at anything less than 70 degrees to the wind with a clean bottom and to within 90 to 120 degrees with a fouled bottom.

There were no steam-ships on the North Atlantic. The first steam-powered ship to cross the Atlantic Ocean was the Savannah, an American converted coastal packet ship, which did not set out on its voyage from Savannah Georgia for Liverpool until 24 May 1819. There was no radar to warn of approaching land ahead and no broadcasts to warn of impending bad weather. Captains and masters had therefore to weigh up in marginal conditions the need to be close enough to a coastline to identify landmarks against the fear that they would get embayed by a sudden increase in wind.

There were no radios for distress calls or weather reports, no rocket apparatus for life saving, no emergency lighting, no life jackets, no life rafts and often only one or two open boats to a ship, and those not life-boats. Such boats as there were seldom contained all the necessities for survival. Whilst they may have been equipped with oars, thole pins or crutches, sails and masts, they often had no compass, no bailers, no sea anchor, no water and certainly no food. Most necessities had to be found and loaded after the ship had sprung a leak or been wrecked, and quite often it was then too late.

2. SOURCE OF THE DATA. The data for this analysis was taken from Shipwrecks of the Revolutionary and Napoleonic Eras ${ }^{1}$, omitting the shipwrecks caused directly by battle and omitting shipwrecks of small boats. All data has its origins in contemporary reports taken from the newspapers of the day, such as The Times, Plymouth and Dock Telegraph and the Sherborne and Yeovil Mercury, and official publications of the day such as the Annual Register.

3. CLASSIFICATION OF SHIPWRECKS. Accidents in modern times are seldom caused by one factor. Often there is a chain of events, triggered by a root cause, and only when these events are combined together does the sequence lead to disaster. When remedial action is taken as soon as the root cause factor becomes evident, then the probability of disaster is often reduced. The same may be said of accidents in the period under review.

Some accidents are easy to classify. A fire leading to the loss of a ship is straightforward, as is a ship parting cables while at anchorage in a port and being 
driven ashore. The more difficult cases are those which are caused by a combination of deteriorating weather conditions, coupled with poor navigational judgements. Weather appears so often as the bogey man, and is indeed the root cause in many of the shipwrecks of the period - but in a number of cases one must ask whether the master was being prudent in trying to enter confined waters at that time, whether he should have hugged a particular coastline under the prevailing weather conditions, whether he should have given a shoal or a known rock a wider berth, or whether he should be sailing under full sail when shoals are known to be in the area. Witnesses were seldom available and detailed records where they existed were often written by the master or the captain of the stricken vessel. Thus the division between weather and navigation classification of causes of shipwrecks reveals a large grey area of overlap, where incidents could with good cause be moved from one category to another. This paper therefore confines itself to causal remarks and comments.

4. RESULTS OF THE ANALYSIS. After eliminating the cases mentioned in para. 2 above, and the 120 ships lost in a hurricane that struck the Bahamas on 24 July 1802, 913 shipwrecks were subject to closer scrutiny. The broad breakdown of the results obtained is shown in Figure 1.

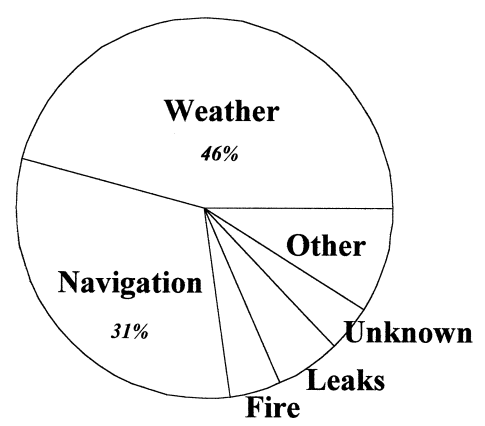

Figure 1. Causes of Shipwrecks 1793-1815.

'Weather' is seen as being the predominant factor in 420 of the shipwrecks $(46 \%)$ and, as will be shown later, weather played a significant part in many more. 'Navigation' appears as the second most probable cause of shipwrecks, being the root cause in 286 shipwrecks ( $31 \%$ ), and a few of these are subject to further examination later in this paper. The next highest cause of shipwrecks is shared by 'Leaks' and 'Fire'. But, bearing in mind that the vessels were made of wood, that all cooking was done on open fires, and that most ships carried cannons and gunpowder, the figure of 42 shipwrecks ( $5 \%$ ) for 'Fire' appears to be rather low. Indeed, the true figure may well be higher because there were at least $5 \%$ of 'Unknowns' and 'Disappeared without Trace'. Although 'Other Causes' accounted for only 40 shipwrecks (4\%) it is possible that this factor could well have been a contributory cause in a number of the 'Weather' and 'Unknown' cases.

5. TYPICAL CASES.

5.1. Weather. The three cases below illustrate some of the problems involved in attributing root causes to shipwrecks when no crash recorder and no voice recorder exists. The selection may well stir unpleasant memories in the minds of modern seafarers who have themselves ventured far and wide in modern yachts and been 
exposed to the elements, albeit with the benefit of satellite navigation and assistance of reliable weather forecasting. The cases will also bring home vividly to landlubbers the undisputed power that exists when wind and wave combine to produce awesome spectacles or to obscure or confuse navigation features.

5.1.1. 25 January 1795, beginning of a disastrous week for the French Navy. After a series of battles with the English fleet under Lord Howe, which lasted from 28 May until 1 June 1794, the greater part of the French fleet returned to Brest for necessary repairs. Brest is an enclosed port, protected from SW'ly and SE'ly gales (Fig. 2). The port does, however, contain many treacherous rocks and shoals, a number of which are only visible at low water.

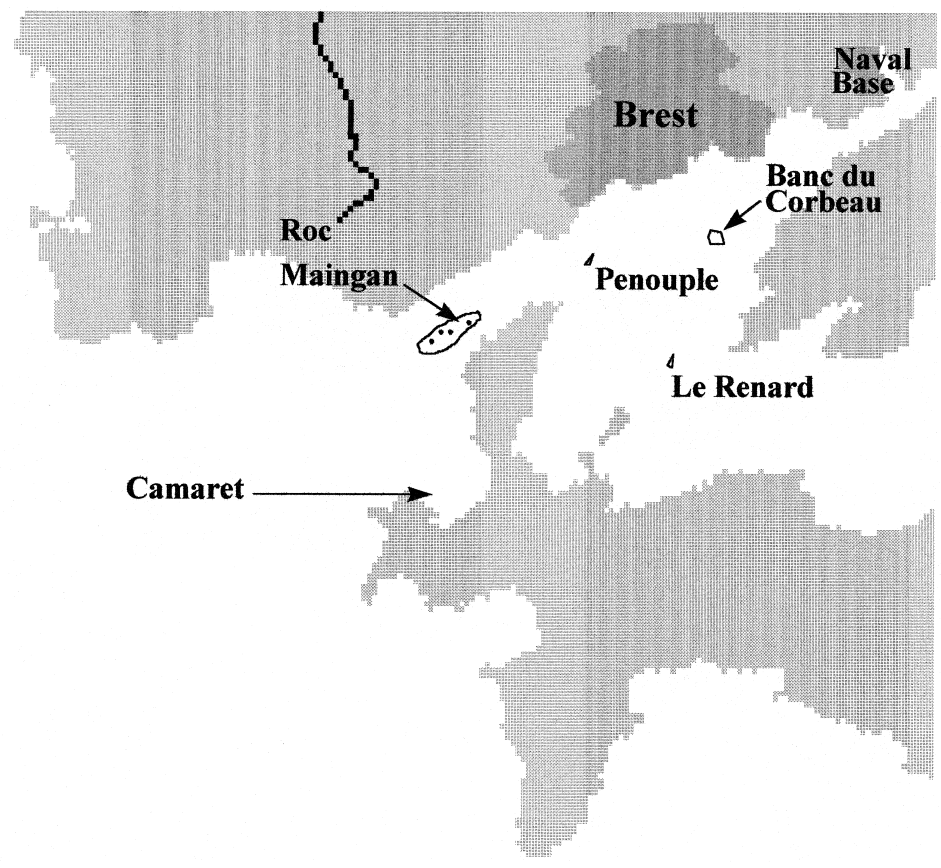

Figure 2. Brest Harbour.

Within the France of 1794 there existed a Committee of Public Safety, a misnomer by any standard, and this august body insisted that the fleet put to sea again. At the beginning of December 1794 the Government of France decided to send six ships, under the command of Rear Admiral Renaudin, to Toulon and required the Brest squadron to sail with this division. The Minister $M$ d'Albarade wrote several despatches to hasten the repair work but the port authorities met great problems in getting the ships ready for sea, due to lack of materials and supplies. The ships of Admiral Renaudin were the only vessels to have provisions for several months; the remainder had to be content with supplies for 15 days. Officers visited Paris to complain, to no avail, and the Committee of Public Safety sent Admiral VillaretJoyeuse at Brest the peremptory order to sail.

On 24 December the 110-gun, three-decker Revolutionnaire, in trying to get under way, struck on the Roc Maingan and became a complete loss. Only the skill and 
presence of mind of her captain saved the Redoubtable from a similar fate, although she lost all of her boats and anchors.

On 29 December Admiral Villaret-Joyeuse led his fleet of 34 ships of the line (four three-deckers, three 80s and the remainder 74s), 13 frigates and 16 corvettes, avisos and tenders into Camaret Roads, a total of 63 ships of war. He sailed from Camaret Roads the next day (Figure 3).

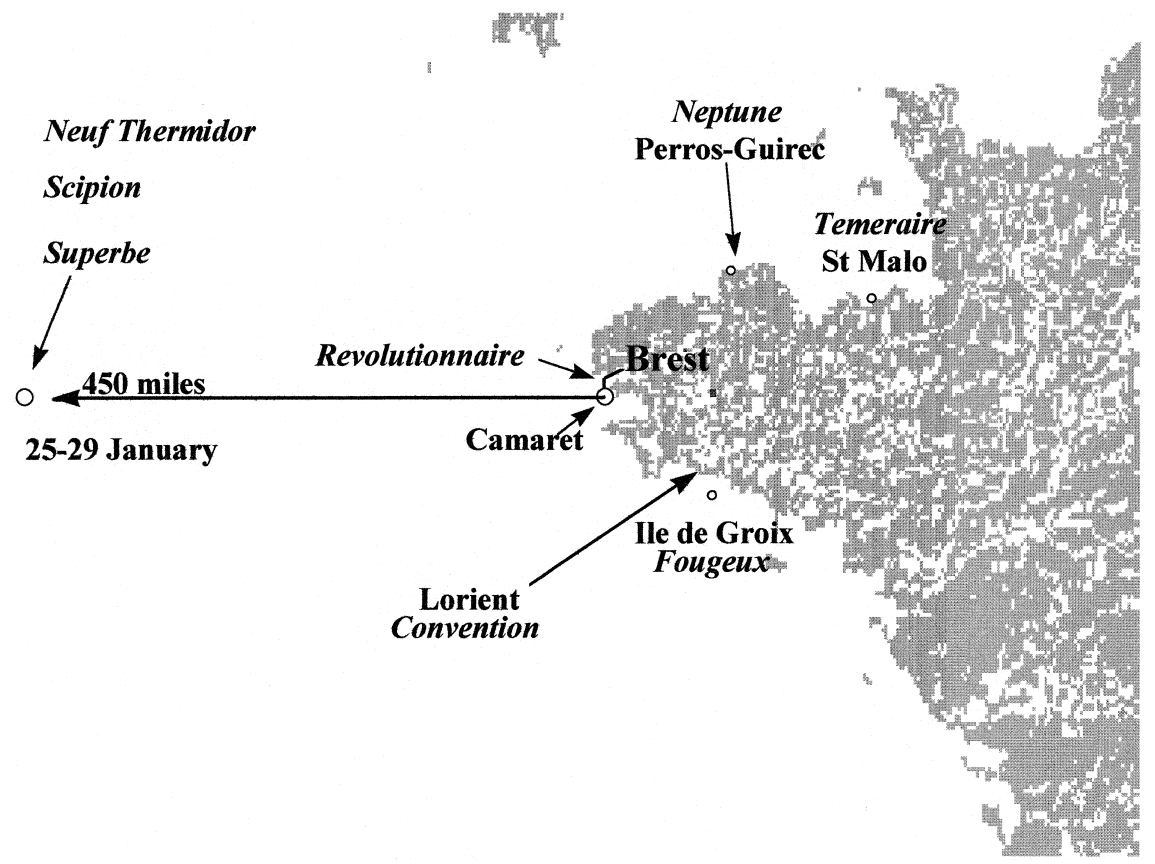

Figure 3. A Disastrous Week for the French Navy.

The dispatch of the Brest squadron at this season exhibited an ignorance on the part of the naval directorate in Paris that beggared belief. The ships were old and had received incomplete repairs and several vessels had their masts jury-rigged and that rigging in very bad condition. The Admiral therefore knew that he had to keep in the offing of the French coast.

Once at sea the squadron experienced easterly gales, and by 25 January they had fetched 450 miles from Brest. The gales worsened, and in the storm that raged from 25 to 29 January, three of the largest ships foundered. First to go was the Neuf Thermidor, which went down with nearly the whole of her crew. The following day, the 26th, the 80-gun Scipion with a crew of 970 foundered, but by good fortune nearly all were saved. The third vessel to go was the 74-gun Superbe.

On 30 January the wind backed to NW which permitted some of the fleet to return to Brest. Others were less fortunate. The 74-gun Neptune ran aground at PerrosGuirec. The 74-gun Temeraire succeeded in reaching St Malo when on the point of going down, the 74-gun Fougeux crept into port at Ile de Groix. The 74-gun Convention reached Lorient with great difficulty and the Majesteux, a three-decker, was so leaky and with seven feet of water in her hold, that she could be barely kept afloat, even at her moorings. 
The cause of most of these shipwrecks has been attributed to weather. However, there is a good case for listing the poor state of repair of the vessels as either the root cause or at least a major contributory cause. And, what about the failure of the Committee of Public Safety and the Naval Directorate in Paris to appreciate all of the factors involved? Surely they must bear some of the responsibility?

5.1.2. 15 November 1795, West Indies Fleet sailed from St Helens IOW. The outbound fleet of some 200 ships under Rear Admiral Christian sailed from St Helens, Isle of Wight, with a favourable wind and was observed on the 17 November off Exmouth Bar (Figure 4). Quoting from contemporary records:

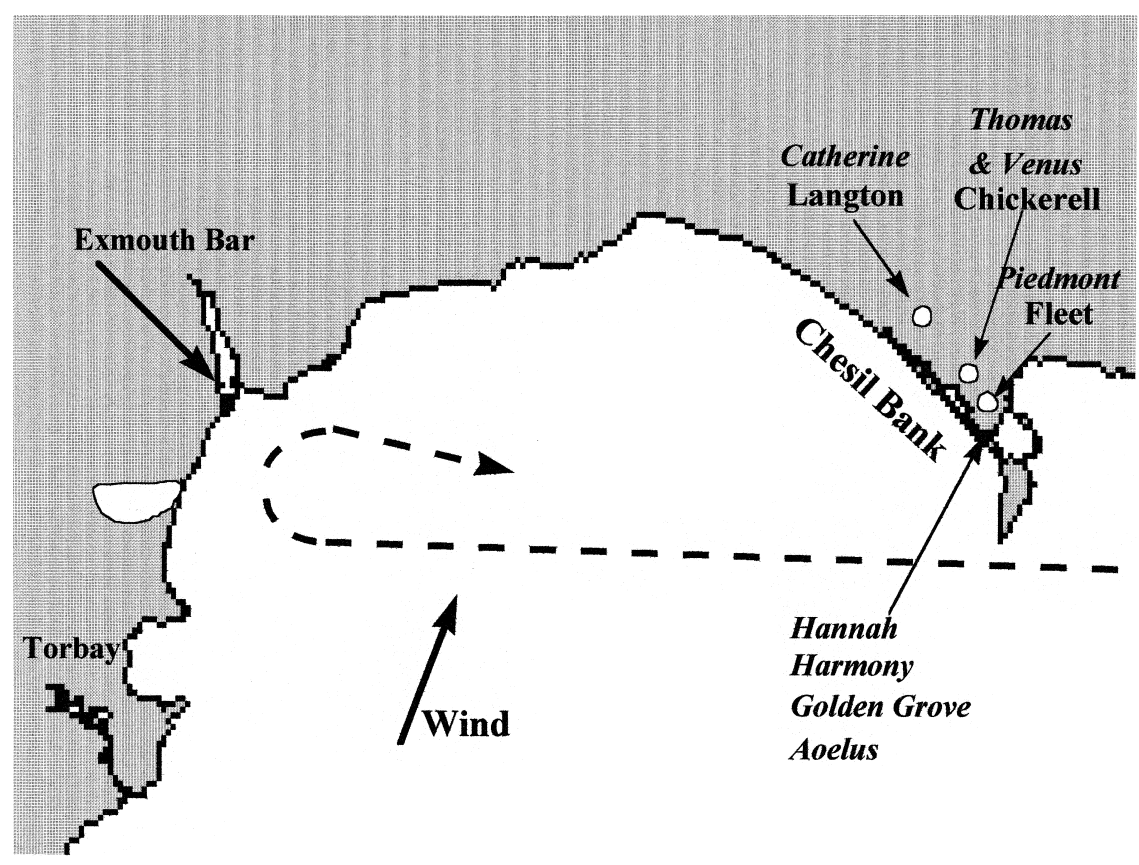

Figure 4. Outbound West Indies Fleet, 15 November 1795.

The wind shifting to SSW the fleet could not then fetch Torbay and had of necessity to put about for Weymouth. The wind increasing to gale force, several of the transports were unable to stand out to sea sufficiently far for them to weather the Isle and Race of Portland, and on the ensuing day, at high tide, a number of the vessels struck on the Chesil Bank, a dangerous lee shore when the wind is in the SW quarter.

The Catherine, Piedmont and Thomas \& Venus were all wrecked opposite the villages of Langton, Fleet and Chickerell. The Hannah, after being run foul of the Harmony, struck at Hill's harbour, the Aeolus and the Golden Grove were wrecked slightly further south and the Pitt struck at St Alban's Head, south of Corfe Castle.

At first sight, one might say that the root cause of the loss of so many ships was simply the lack of a reliable weather forecast, and I have therefore attributed the losses to the weather. But on closer examination, doubts start to creep in. First, of all the ships lost on the Chesil Bank, not one was a naval vessel. The ships were transports conveying troops and supplies to the West Indies and were wretchedly crewed by landsmen who would never dream of climbing a ship's rigging during a 
gale. And if they were made to do so, under threat of some of the cruel punishments handed out by ships' captains, would they have performed the operation in a timely manner? The best sailors, if not the only sailors, had been taken by press gangs for the Navy. Secondly, there is the question of when the Admiral should have put about. Had he made the decision as soon as the wind started to increase, it is possible that the transports may have got around the Isle and Race of Portland instead of being embayed on a lee shore.

It is of interest that the remnant of this fleet was back in St Helens on 19 November and sailed again on 3 December carrying 16,000 troops. It was too late in the year to embark on such an adventure and the ships were again caught in a gale and dispersed on 12 December. That night they had the misfortune to fall in with the returning Lisbon fleet when in position $48^{\circ} 30^{\prime} \mathrm{N} 09^{\circ} 41^{\prime} \mathrm{W}$. In this encounter the Leander collided with the transport Commerce, which went down with the loss of 1300 men.

Life was hard for troops on board the transports, but it was little better when aboard ship in port. The record shows that earlier in 1795 one regiment lost 400 of their 600 men because they contracted Typhus on board ship at Plymouth. Orders were given to disembark all regiments that could not muster 400 men. The 700 merchant ships present in the confined area of Plymouth Sound were ordered to sail for Portsmouth.

5.1.3. 2 November 1801, severe gales struck Western Europe. Their effect is probably best summed up in the report of the captain of the ship Elizabeth, which arrived at Hull on 20 November 1801. He reported that on his passage between Anholt, Denmark, and Elsineur [Elsinore], he observed 14 vessels completely wrecked, six of them bottom upwards.

The same storm affected shipping in the Channel area, and the Plymouth report for 2 November stated:

Wind SW. Blows a hurricane at SW and NW. Last night and this morning the hurricane at SW and NW was the most dreadful seen for many years; the sea ran mountains high. Several ships broke adrift, and a large American ship went ashore in the Catwater, where she lies bilged.

The storm of 2 November was also fraught with trouble for many ships in the Channel Islands. Among the casualties was the gunboat Friendship which was driven out of the Guernsey Roads and driven ashore at St Malo, where the crew managed to get on to a rock, wading ashore on the morning of 3 November.

5.2. Navigation. The four cases of navigation errors illustrated below are typical of the types of navigation errors that occurred throughout the period.

5.2.1. 15 December 1793, Pigmy-Torbay to Plymouth. Perhaps the most common navigation error, which is also prevalent today, is the misidentification of a visual feature. The disaster that befell the vessel Pigmy on 15 December 1793 typifies the problem. Summer visitors regard South Devon as an area that possesses a beautiful coastline with many indentations and small rivers, leading to places such as Dartmouth, Salcombe and Newton Ferrers. But in the winter months, South Devon is also noted for the mildness of the weather, there being a prevailing SW'ly airstream with low cloud and drizzle.

The Sherborne and Yeovil Mercury of 23 December reported that the Pigmy sailed from Torbay on the morning of 15 December with the wind at SSW, bound to Plymouth. In the course of the day the wind backed further south and increased to 
gale force, attended with very hazy weather. About six o'clock in the evening, the watch mistook the shore near Motherbank for the entrance to Plymouth (Figure 5). They let go two anchors, but these failed to hold and they were driven on to the rocks and by eleven o'clock were dashed to pieces.

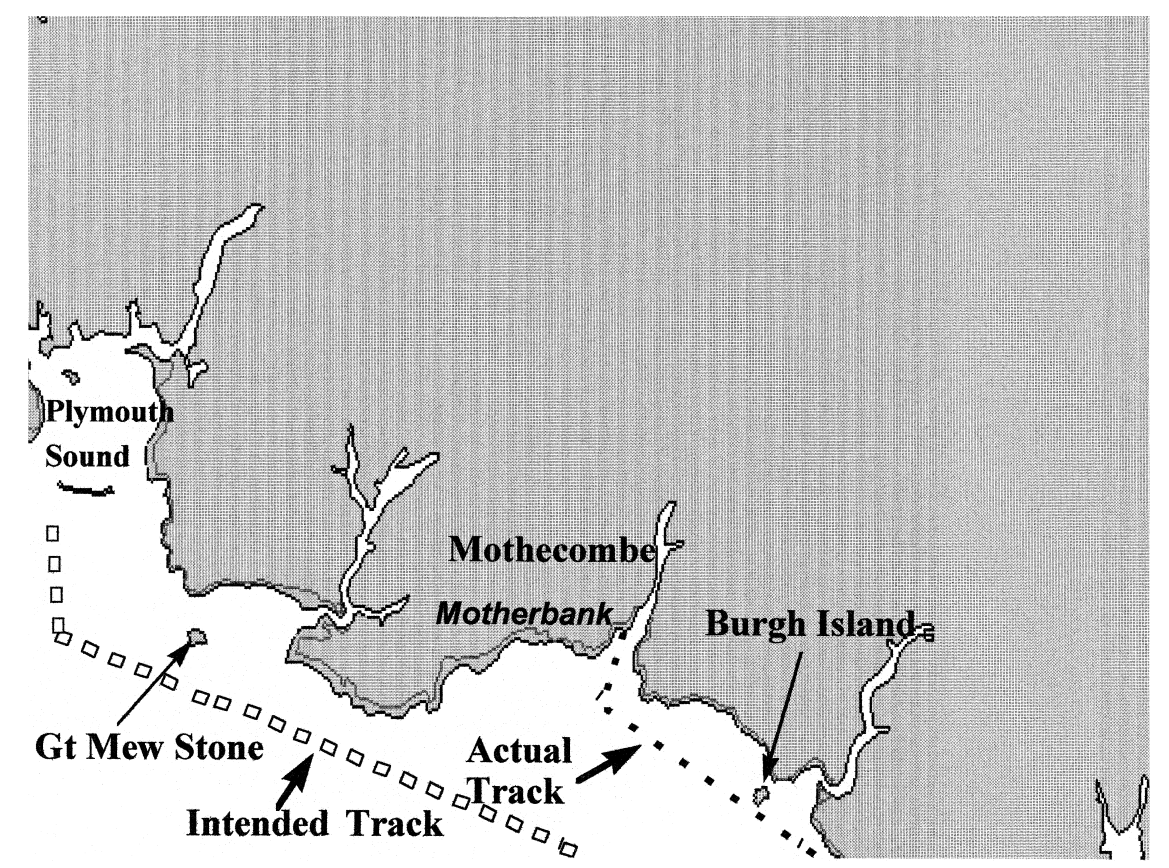

Figure 5. Pigmy Misidentifies the Approach to Plymouth Sound.

Figure 5 illustrates how easy it is to mis-identify inlets in conditions of bad visibility. The crew of the Pigmy could well have been looking out for the Great Mew Stone which stands just to the east of Plymouth Sound. The Sherborne and Yeovil Mercury reported that the weather at the time of the shipwreck was extremely hazy and the wind foul. It appears that when they spotted Burgh Island, followed by an estuary, they thought that they were about to enter Plymouth Sound; instead they faced St Mary's Rocks and the Erme Estuary.

5.2.2. 2 April 1804, Apollo plus 69 sail in convoy for West Indies and Lisbon. On 26 March 1804 the Apollo sailed from the Cove of Cork in company with the Carysfort frigate and sixty-nine sail of merchantmen under their convoy, bound for the West Indies, but with others for Lisbon and Madeira. They set out with a fair wind, blowing a strong gale, which moderated and veered to the westward on 31 March. On Sunday 1 April, Apollo's dead reckoning position was $40^{\circ} 51^{\prime} \mathrm{N} 12^{\circ} 29^{\prime} \mathrm{W}$ (Figure 6) and that evening the wind backed to the southwest.

Course at this time was reported as SSE. Later that evening it became squally, and at half-past eleven the main-top sail split; it was furled as was the main sail, so the ship was now under her foresail. It was noted that the wind was blowing hard with a heavy sea.

At half-past three on Monday morning 2 April, the Apollo struck hard and repeatedly, to the astonishment of everyone on board, who conjectured that they had 


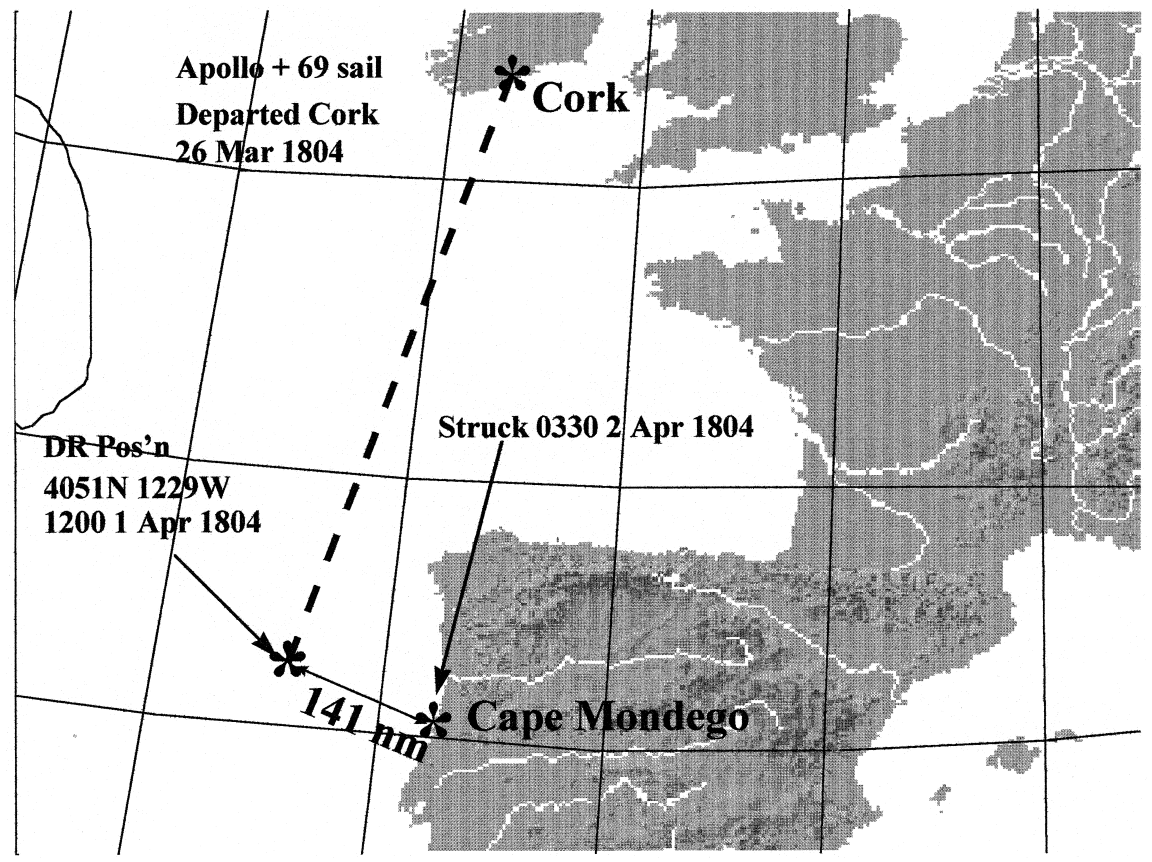

Figure 6. Route of Apollo and 69 Sail Convoy.

hit an unknown shoal. The vessel continued striking the ground, very heavily, several times, by which time the bottom was materially damaged and taking much water. The chain pumps were rigged with the utmost dispatch and the men began to pump. But in ten minutes she beat and drove over the shoal. The crew then discovered that the rudder had been carried away, and the ship got before the wind. The pumps were kept going but to no avail as the ship gradually filled and started to sink. Five minutes later the ship struck heavily and water started to break over her. The weight of the guns on the quarter-deck tore away the bulwark making the ship a perfect wreck abaft. The ship had struck nine miles north of Cape Mondego. When daylight came, the crew of Apollo perceived between twenty and thirty sail of the convoy ashore -i.e. about $40 \%$ of the total, but in true count some 40 ships or $58 \%$ were lost. The dead reckoning error was some $141 \mathrm{~nm}$ in a run of $688 \mathrm{~nm}$; an error of $20 \%$. If such errors were commonplace, one must question the judgement of the captain of Apollo in pursuing a course of SSE on a pitch black night.

5.2.3. 25 December 1810, L'Aimable mistook lights ashore. L'Aimable was running at nine knots, with a pilot aboard, off Berwick-upon-Tweed for May Island, when the light on a lime kiln on shore was mistaken for the light of May Island. An identical mistake had been made exactly one week before when the Pallas and the Nymphe, again with a pilot aboard, not only mistook this light but also mistook the Isle of May light for the light on Bell Rock, causing both ships to be wrecked four miles from Dunbar.

5.2.4. 26 March 1803, La Determinee, Normont Point Jersey. My last navigation case will be seen by mariners as simply bad luck, but will no doubt be seen by the legal profession as an error of judgement. It refers to the La Determinee, on 23 March 1803. As Captain Becher of La Determinee was ready to sail from Spithead on 23 March 
1803 in company with the Aurora, he sent an officer ashore to request a pilot. None could be provided so Captain Becher made an application to the flag-ship, which was equally unsuccessful. He then set sail in the belief that he could obtain a pilot at Cowes. There he anchored and made a signal for a pilot, but to no avail. The next morning he made two further attempts to get a pilot and when these were unsuccessful he decided to follow the Aurora to Yarmouth. Again, he tried to obtain a pilot and again he failed. He discussed the situation with the master and they jointly decided to follow Aurora closely to Jersey. Although he tried hard to keep in Aurora's wake, he unfortunately stuck a rock as he was entering harbour and the ship was wrecked. At a subsequent court-martial he was honourably acquitted for the loss of the ship.

5.3. Fire. The causes of fire and explosion were many and varied. Some were caused by fires used for cooking not being properly extinguished, some were caused by the carelessness when heating shot in a forge, some were caused by less than strict procedures for the control of gunpowder and some were caused by lightning. The following examples are typical.

5.3.1. 20 November 1793, Le Scipion in Leghorn harbour. Leghorn harbour is an enclosed narrow rectangular area. Le Scipion, with its crew of six hundred Frenchmen - mainly invalids - had been taken by Lord Hood at Toulon and was in Leghorn harbour to take on provisions and livestock for the populace of Toulon. At $1500 \mathrm{hrs}$, large volumes of smoke were observed issuing from various parts of Le Scipion, followed shortly after by flames, which caught the rigging and sails. The crew then began jumping overboard and jolly boats from the British, Spanish and Neapolitan men-of-war picked up many of them, but the invalids were not so fortunate. Of the six hundred members of the crew on board when the fire started, three hundred and ninety perished. By four o'clock the portholes of the cannon resembled so many furnaces and the whole threatening to set fire to other shipping in the harbour. The guns, loaded with grapeshot or balls, were continually going off and threatening all the shipping in the harbour. Rear Admiral Cosby, aware of the danger, and aware that Le Scipion had three hundred barrels of gunpowder on board, ordered the British squadron to put to sea. Unfortunately, the French ship severed its moorings, drifted out to sea in the strong easterly wind, passing the British squadron and blew up at 8 p.m. The fire was caused by a barrel of brandy being set on fire by a candle burning near it.

5.3.2. 7 August 1798, Royal Charlotte at Culpee (50 miles from Calcutta). On this thundery day, two East India ships, the Britannia and Royal Charlotte, had taken many passengers on board at Culpee and, as part of the cargo, each ship was laden with about five hundred barrels of gunpowder for the Cape. Unlike American and French ships of the period, the East Indiamen had no lightning conductors, and the magazines were ill constructed with the foremasts running through them. When lightning struck, the Royal Charlotte blew up, and the entire crew and passengers were killed (140 persons).

5.3.3. 11 January 1799, Ganges in Lacam's Channel near Calcutta. The Ganges came to anchor to the eastwards of Lacam's Channel near Kulpi on the approach to Calcutta, and the Laurel, another East Indies ship, was about twelve miles astern. Captain Wade and his officers were walking the deck of the Ganges when they detected a disagreeable smell of burning oil and smoke came from below. The gunroom was immediately cleared and, upon opening the scuttle of the aft gunroom, 


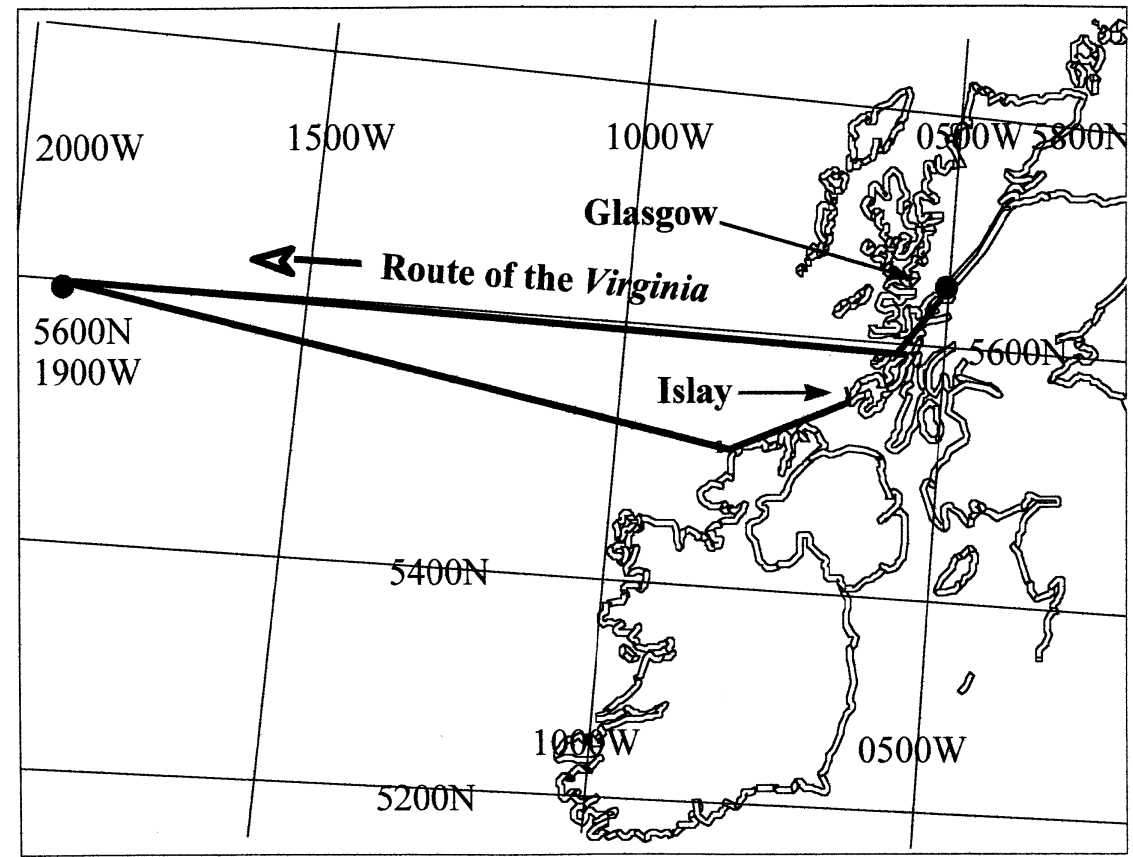

Figure 7. Virginia, enroute, Clyde to USA, 26 November 1794.

smoke rushed out and plainly indicated that to be where the mischief lay. Captain Wade ordered all gunpowder to be removed from the gunroom while he himself together with the officers and some crew members threw water into the aft gunroom, but had to retreat because of the smoke. The Ganges carried only one boat, and as a measure of prudence, Captain Wade ordered the boat out. But this was no sooner done than thirty or forty of the crew jumped into it and the officers found it necessary to push off in order to prevent the boat from becoming surcharged. Those left on board had now to fight the fire and to construct rafts. However, before they could do this, the magazine blew up. The Laurel rescued fifty-nine men from the boat that had been launched from the Ganges.

The cause of the fire was spontaneous combustion of a small quantity of wood oil contained in a leathern jar stowed in the gunroom. A fire originating from this cause occurred in the arsenal in Fort William in 1794, but regrettably the lesson had not been communicated to all.

5.3.4. 17 March 1800, Queen Charlotte cruising between Gorgona and Leghorn. At six o'clock in the morning of 17 March 1800, the Queen Charlotte, when cruising between Gorgona Island and Leghorn, caught on fire because a match used to fire signal guns, and which was kept in a tub, had made contact with some loose hay lying under the half deck. The fire spread rapidly, the ship burnt to the water's edge and then blew up. Seven hundred lives were lost.

5.4. Leaks. Leaks, leading to sinking or oversetting, accounted for about the same number of shipwrecks as did 'Fire'. British ships were not noted for being free of leaks and it is therefore not surprising that British sailors were always pleased to acquire French or American ships, which were better caulked. 
5.4.1. 26 November 1794, Virginia bound from the Clyde to the USA. This is a tale of good seamanship ruined by very bad luck.

On 19 November 1794, the Virginia sailed from the Clyde in ballast and by 24 November had reached $56^{\circ} 00^{\prime} \mathrm{N} 19^{\circ} 00^{\prime} \mathrm{W}$, (Figure 7) when they discovered that the ship had sprung a leak and very quickly there was five feet of water in the holds. The wind was blowing hard from the NNW and, although both pumps were working, the water in the holds did not reduce. This induced the master to bear away for Ireland. Two days later the water in the holds had increased to seven feet-this despite the passengers and crew pumping continuously. They were so fatigued and certain that the ship would sink that they took to the longboat when 400 miles offshore. Fifteen minutes later they shipped a sea, and in a moment of panic, threw all provisions overboard to prevent the longboat sinking. Luck was not with them and when they got to within sight of the Irish coastline the wind shifted to the southward, and they bore away for Islay. On Sunday 30 November, they attempted to land on the NW side of Islay, where the combination of a strong ebb tide and heavy surf swept the boat upon a reef. Six survived to tell the tale.

5.5 Ice and Icebergs. While not a significant factor in this analysis, one shipwreck merits special attention because it reflects on the decision to sail late in the season and questions the judgement of the master when adverse weather conditions were met.

5.5.1. 30 July 1807, Ann-Newry to Archangel. On 17 July 1807, Ann sailed from Newry, Northern Ireland, for Archangel. The Ann was a good ship and had previously made a voyage to Archangel, but the opening prospect was gloomy. The season was far advanced and after a couple of days the wind blew in a violent manner from the SE with heavy rain and almost impenetrable fogs which drove them

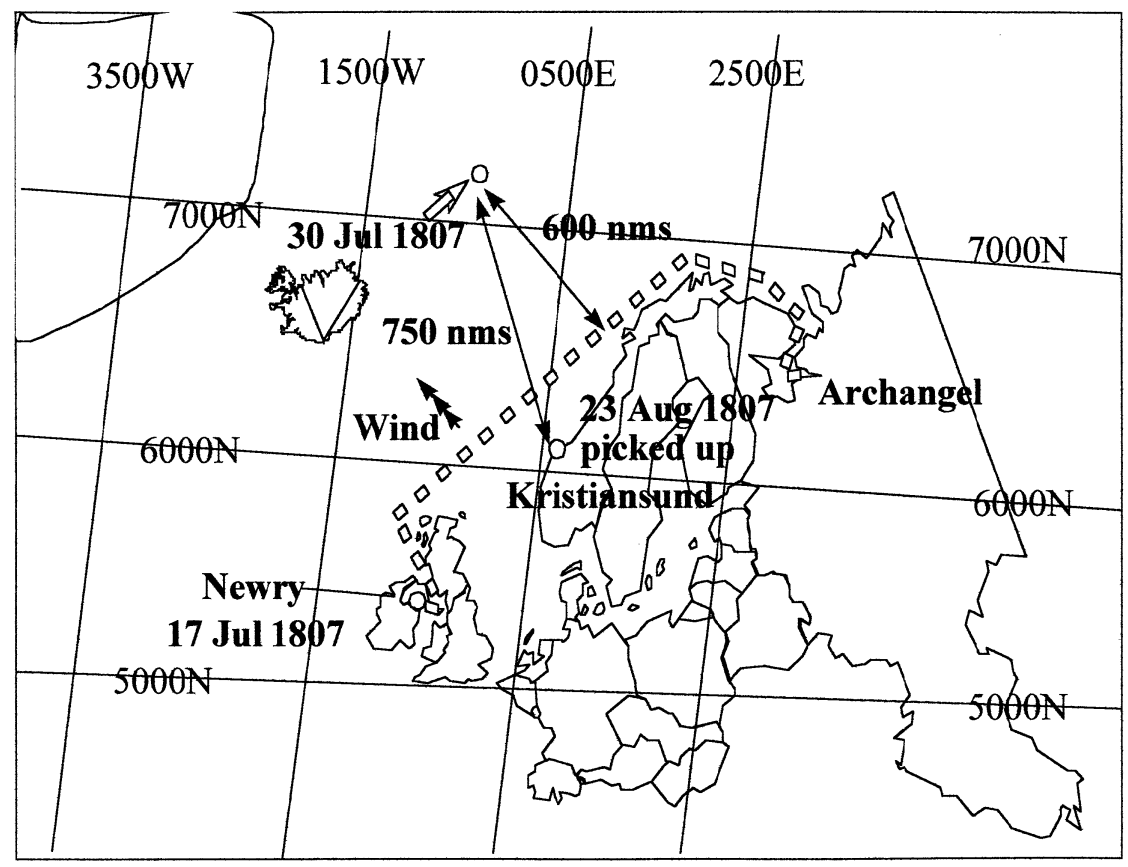

Figure 8. Ann- Newry to Archangel. 
to the northward and eastward. When they managed to obtain observations they found that they were in a position $70^{\circ} 00^{\prime} \mathrm{N} 10^{\circ} 00^{\prime} \mathrm{W}$, (Figure 8) some $600 \mathrm{~nm}$ off track. The fog lifted to reveal the vessel surrounded by tremendous mountains of ice. The gale was still raging and the ship could not tack to avoid the flows and one, which struck and entered the starboard bow, threw the ship on to her beam ends, from which position she never recovered. They tried without success to fetch Jan Mayen island and, when the pumps failed to keep pace with the inflow of water, they had to take to the boats.

They shaped their course for Norway in their open boats, with the spray of the sea breaking over them and on the 23rd day, when close to the Norwegian coast, they were rescued by Norwegian fishermen.

Although the cause of this shipwreck was attributed to ice, one could argue for two possible root causes. Was the master of the Ann wise to start out on the voyage so late in the season? And was the master wise to continue when he met gales rather than to head for shelter in a Scottish or Faroes port?

6. AN EPIC JOURNEY BY SHIPWRECKED MARINERS. The Sydney left Port Jackson on 12 April 1806 for Bengal, following the route of the Cornwallis, which appeared to be a safe passage. However, on 20 May in position $03^{\circ} 20^{\prime} \mathrm{S} 146^{\circ} 50^{\prime} \mathrm{E}$ (Figure 9), the Sydney ran upon a shoal at high tide and soon broke

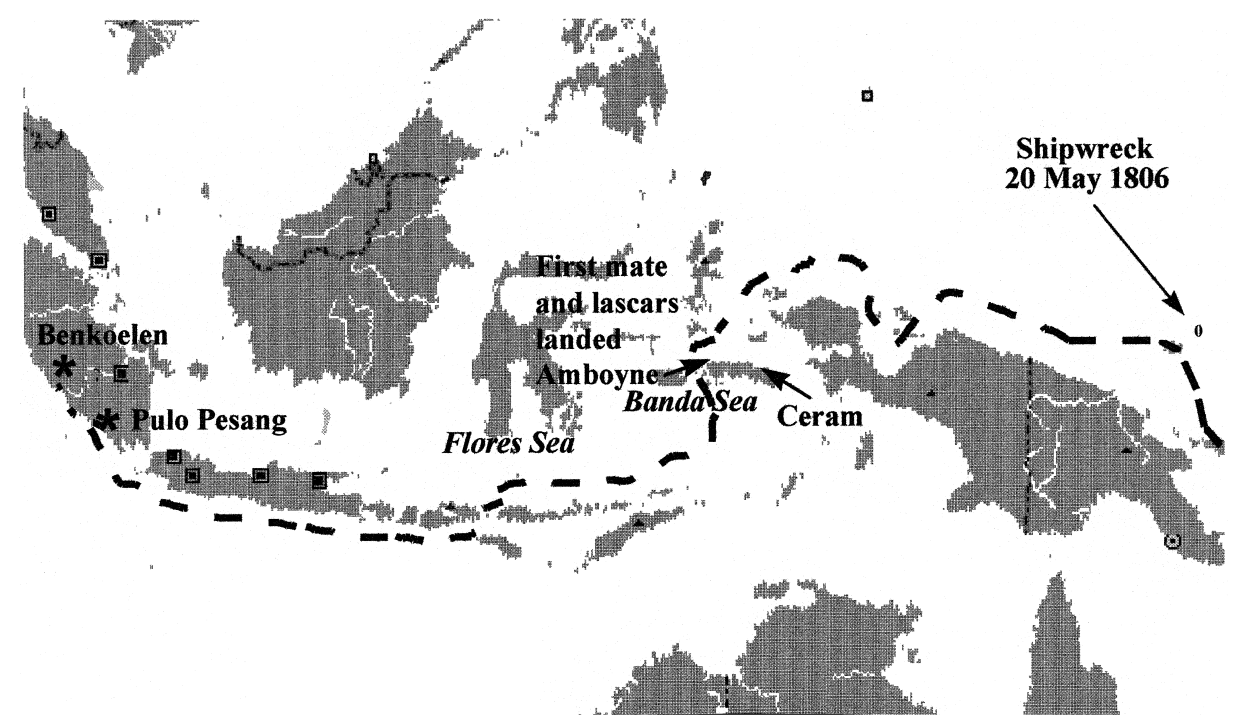

Figure 9. 4000-mile Journey of Shipwrecked Mariners.

up. Soundings at the stern over the taffrail before the break-up showed a depth of 25 fathoms and soundings ten fathoms astern of the vessel showed no ground at 60 fathoms. The crew and passengers took to the three boats and shaped their course for the Admiralty Islands. The next day the wind increased and the jolly boat, which was being towed by the cutter, sank with the loss of the 16 men on board.

On 22 May, they saw the Admiralty Islands at a distance of nine miles, but with a strong easterly wind they could not land. Their course now took them along the coast of New Guinea and through the Dampier Straits to Ceram where the first officer 
and the lascars landed and made their way to Dutch-held Amboyne. So far, their journey amounted to 1500 miles. After passage through the Banda and Flores Seas, they sailed through the Sape Strait to Pulo Pesang, where they were too weak to get up the anchor. They made a signal of distress, whereupon a sandpan came out and took the captain ashore. Refreshments were provided to all, and three days later they sailed on to Benkoelen, to complete a journey of 4000 miles. This is believed to be the longest journey ever made by shipwrecked mariners.

7. CONCLUSION. It would be a brave man, or perhaps an unwise man, who would say that an analysis of shipwrecks for a period of history more than 200 years ago might be regarded as scientifically sound. All this analysis has tried to do is to give the general trend of the causes of shipwrecks, to illustrate typical cases, to reflect on how the elements and the practice of good navigation are inextricably intertwined, and how the failure to heed warning signs can subsequently place a craft in peril.

\section{REFERENCE}

${ }^{1}$ Grocott, T. (1998). Shipwrecks of the Revolutionary and Napoleonic Eras. Chatham Publishing, London. ISBN 1861760302.

\section{KEY WORDS}

1. Accidents. 2. History. 3. Sea.

